\title{
PERLINDUNGAN HUKUM BAGI KARYA FOTOGRAFI YANG DIUNGGAH DI MEDIA INTERNET
}

\author{
Solehoddin \\ Fakultas Hukum, Universitas Widyagama Malang, Indonesia. \\ Email: helos_udin@yahoo.co.id
}

\begin{abstract}
Abstrak
Karya fotografi merupakan sebuah kegiatan atau proses menghasilkan suatu seni gambar/foto melalui media cahaya dengan alat yang disebut kamera sehingga menghasilkan nilai estetika atau keindahan yang memancar dalam karya tersebut. Karena dalam prakteknya masih terdapat banyak pelanggaran mengenai Hak Cipta yang salah satunya merupakan pelanggaran terkait karya seni fotografi yang karyanya dipublikasikan tanpa seizin pemilik hak cipta (fotografer), dalam rangka untuk melindungi pemilik karya tersebut terdapat Undang-Undang RI No. 28 Tahun 2014 tentang Hak Cipta sebagai acuan ketika terjadi sengketa pelanggaran hak cipta salah satunya mengenai fotografi. Guna menjawab permasalahan tersebut, peneliti menggunakan metode penelitian hukum normatif dimana penelitian ini bertujuan mengkaji dan menganalisis menggunakan berbagai bahan hukum sekunder seperti peraturan perundang-undangan, teori hukum, dan juga dapat berupa pendapat para sarjana.
\end{abstract}

\section{Kata Kunci : Perlindungan Hukum; Karya Fotografi; Hak Cipta.}

\begin{abstract}
Photographic work is an activity or process of producing an image / photo art through light media with a device called a camera so as to produce aesthetic value or beauty that radiates in the work. Because in practice there are still many violations regarding copyright, one of which is a violation related to photographic works of art whose work is published without the permission of the copyright owner (photographer), in order to protect the owner of the work, there is Law of the Republic of Indonesia No. 28 of 2014 concerning Copyright as a reference when a copyright infringement dispute occurs, one of which is about photography. In order to answer these problems, researchers used normative legal research methods where this study aims to study and analyze using various secondary legal materials such as statutory regulations, legal theory, and also the opinions of scholars.
\end{abstract}

\section{Keywords: Legal Protection; Photographic Works; Copyright.}

\section{A. PENDAHULUAN}

Fotografi merupakan sebuah karya seni hasil dari cara kreatif manusia untuk menciptakan gambar atau foto yang dihasilkan melalui media cahaya dengan alat yang disebut camera. Melalui camera, hasil potret fotografi menjadi sebuah karya seni yang memiliki nilai estetika dimana keindahan dari foto yang dihasilkan tersebut bisa membuat orang merasakan menghayati sebuah karya fotografi. Karena fotografi memiliki nilai estetika atau keindahan, banyak orang yang menyukainya bahkan tak heran jika karya tersebut dapat diperjual belikan oleh fotografer sebagai ide bisnisnya. Salah satu media untuk mejadikan karya seni fotografi sebagai ladang bisnis adalah dengan memanfaatkan media internet. Media internet merupakn suatu sistem jaringan yang dipakai untuk menghubungan komputer atau hp dan sejenisnya untuk salaing terhubung antara satu dengan lainnya di seluruh belahan bumi. Dengan media internet orang akan dengan mudah menemukan apa yang ia butuhkan. Karya seni fotografi 
yang dihasilkan oleh fotografer merupakan hak milik atas dirinya, sebagai suatu karya seni yang lahir dari kemampuan intelektual sang fotografer.

Berbicara mengenai kemampuan intelektual, didalam kajian hukum terdapat yang namanya Hak Kekayan Intelektual. Hak Kekayan Intelektual (HKI) adalah hak atas kekayaan yang timbul atau lahir dari kemampuan intelektual manusia. Kemampuan intelektual manusia dihasilkan oleh oleh manusia melalui daya, rasa, dan karsanya yang diwujudkan dengan karya-karya intelektual dan mampu memiliki nilai ekonomi. ${ }^{1}$ HKI secara umum dapat digolongkan dalam dua kategori utama yaitu hak cipta dan hak kekayaan industri. Ruang lingkup hak cipta adalah karya cipta dalam bidang ilmu pengetahuan, seni, dan sastra. Sedangkan ruang lingkup Hak Kekayaan Industrii adalah dalam bidang teknologi. Dalam terminologi HKI dikenal istilah "pencipa" dan atau "penemu".

Sebuah karya fotografi ketika sudah berwujud atau dipublikasikan ke khalayak umum, maka sang pencipta (fotografer) sejak pertama kali mempublikasikan karyanya maka saat itu pula karya fotografi tersebut dilindungi hak ciptanya. ${ }^{3}$ Hak Cipta menurut Pasal 1 ayat 1 UU No. 28 Tahun 2016 tentang Hak Cipta mengatakan "Hak Cipta merupakan hak eksklusif pencipta atau pemegang hak cipta yang timbul secara otomatis berdasarkan prinsip deklaratif apabila suatu ciptaan sudah diwujudkan dalam bentuk nyata tanpa mengurangi pembatasan yang sesuai dengan ketentuan peraturan perundang-undangan." ${ }^{\prime 4}$ Berdasarkan pengertian diatas karya fotografi merupakan objek dari hak cipta. Karena Hak Cipta merupakan suatu kepemilikan atas karya seseorang, maka perlu adanya perlindungan hukum terhadap karyanya agar karya tersebut tidak dijiplak maupun diakui oleh orang lain seperti pada contoh kasuskasus berikut ini:

1. Andrew Paul Leonard melawan Perusahaan Stemtech Health Science

Fotograferspesialisfoto-fotomikroAndrewPaulLeonardmemotretselindukdisumsumtulang belakang manes pada tahun 1995. Beberapa tahun kemudian, foto-foto tersebut digunakan oleh Stemtech tanpa izin khusus dari Paul Leonard untuk kepentingan pemasaran dan website perusahaan tersebut. Paul Leonard lalu membawa perusahaan kesehatan itu ke pengadilan. Hasilnya, pada tahun 2008, pengadilan memutuskan Stemtech bersalah. Stemtech diminta membayar kompensasi hingga USD 1,6 juta kepada Paul Leonard.

2. Nussenzweig melawan DiCorcia

Kasus ini cukupunik. Yakni saat fotografer Philip-Lorca DiCorciamemotretkomunitas Yahudi Hasidik di jalanan umum di New York. Salah satu jepretan DiCorcia yakni memotret salah seorang anggota Yahudi Hasidik yang melintas bernama Ermo Nussenweig bergaya portrait. Kemudian DiCorcia menjual 10 cetakan gambar Nussenzweig tersebut kepada agensi foto Pace/McGill. Nilai totalnya antara USD 20.000 hingga USD 30.000, Nussenweig menilai tindakan DiCorcia sebagai aksi komersial tanpa ia ketahui sebelumnya. Nussenweig lalu menuntut DiCorcia dan agensi foto tersebut ke pengadilan. Setelah proses pengadilan, juru foto DiCorcia dinyatakan tidak melanggar dan dimenangkan. Pengadilan menilai bahwa foto itu adalah karya seni, bukan tindakan komersial dan dilindungi oleh Amandemen Pertama konstitusi AS.

3. Reinsdorf vs perusahaan sepatu Skechers

Fotografer komersial Richard Reinsdorf menggugat salah satu kliennya yakni perusahaan sepatu Skechers. Reinsdorfmenuduh Skechers menggunakan foto-fotonya dengan melakukan

${ }^{1}$ Andy Noorman Sommeng.(2007). Penegakan Hukum Di Bidang Hak Kekayaan Intelektual, Direktorat. Tanggerang: Jenderal Hak Kekayaan Intelektual, hlm. 10.

${ }^{2}$ Iswi Hariyani.(2010). Prosedur Mengurus HAKI yang benar, Yogyakarta: Pustaka Yustisia, hlm. 17

${ }^{3}$ Hak Eksklusif dalam hal ini adalah bahwa hanya pemegang hak ciptalah yang bebas melaksanakan hak cipta tersebut, sementara orang atau pihak lain dilarang melaksanakan hak cipta tersebut tanpa persetujuan pemegang hak cipta.

${ }^{4}$ Pasal 1 ayat 1 UU No. 28 Tahun 2016 tentang Hak Cipta 
olah digital tanpa sepengetahuan Reinsdorf. Kemudian foto-foto itu dipergunakan lagi pada berbagai media promosi di luar kesepakatan awal. Fotografer Reindorf menilai tindakan Skechers membuat keuntungan perusahaan tersebut mencapai $\$ 250$ juta dari hasil penjualan dengan menggunakan foto-fotonya. Reindorf lalu menggugat ke pangadilan namun kalah. Sebab, pengadilan menilai tidak ada hubungan sebab-akibat yang kuat antara pelanggaran foto dengan pendapatan perusahaan. ${ }^{5}$

Hal seperti kasus diataslah yang dapat meimbulkan berbagai macam problem, masalahmaslah hukum berkaitan dnegan hak cipta, karena sebuah foto adalah sebuah karya cipta yang dilindungi oleh undang-undang Hak Cipta. Oleh karena itu apabila seseorangg ingin menggunakan sebuah karya foto orang lain harus mendapat izinn dari pemegang hak cipta foto tersebut. Bagi setiap pencipta karya seni termasuk pula fotografer dimana mereka diberikan hak untuk memperbanyak dan melakukan perubahan pada karyanya tersebut dan dapat melarang siapapun melakukan tindakan tersebut tanpa seizin penciptanya. Pada umumnya banyak kasus-kasus pelanggran hak cipta terjadi didalam media internet. Pelanggaran atas hak cipta pada umumnya terjadi karena beberapa hal, yakni :

1. Minimnya kesadaran untuk menghargai hak cipta orang lain

2. Adanya keinginan untuk meminimalisir resiko dalam kepentingan komersial

3. Kurangnya keperdulian akan inovasi sebuah karya seni

4. Tingginya permintaan pada karya seni fotografi pada event-event tertentu

5. Rendahnya pemahaman masyarakat pada Undang-undang Hak Cipta

Untuk menjamin keorisinalitasan sebuah karya seni fotografi dan untuk memberi kepastian hukum bagi fotografer yang karyanya dimuat dimedia internet tanpa seizin darinya, maka diperlukan perlindungan hukum agar hak-haknya sebagai pemilik danpencipta karya terjamin oleh undnag-undang. Perlindungan hukum adalah suatu perlindungan yang diberikan kepada subyek hukum ke dalam bentuk perangkat baik mencegah atau mewakili, baik yang lisan maupun yang tertulis. Dengan kata lain dapat diberikan perlindungan hukum sebagai suatu pembahasan terpisah dari hukum itu sendiri yang memiliki konsep hukum menyediakan suatu keadilan, ketertiban, kepastian, manfaat dan kedamaian. ${ }^{6}$ Beberapa ahli hukum mengungkapkan pendapatnya mengenai pengertian dari perlindungan hukum, yakni :

1. MenurutCSTKansil,PerlindunganHukumadalahberbagaiupayahukumyangharus diberikan oleh otoritas penegak hukum unuk memberikan rasa aman, baik pikiran maupun fisik dari masalah dan berbagai tantangan dari pihak manapun.

2. Menurut Satjipto Raharjo, menyetujui bahwa perlindungan hukum untuk memberikan hak pengampunan kepada orang lain, dan memberikan perlindungan kepada orang lain agar mereka dapat menikmati semua hak-hak yang diberikan oleh hukum.

3. Menurut Philipus M. Hadirin, keputusan tentang Perlindungan Hukum adalah harkat dan martabat, serta pengakuan terhadap hak-hak asasi manusia yang diminta oleh subyek hukum sesuai ketentuan hukum dari kesewenangan.

Perlindungan hukum dalam penelitian ini, peneliti menacu perlindungan hukum yang dicetuskan oleh Satjipto rahardjo. Permasalahan yang sering timbul yakni bagaimana perlindungan hukum bagi karya seni fotografi dan bagaimana hal yang dapat dilakukan jika sebuah karya seni fotografi dipublikasikan tanpa seizin pencipta (fotografer). Perlindungan yang diberikan kepada karya cipta fotografi dapat dilakukan dengan 2 cara, yaitu: pencegahan pertamayang diberikan pemerintah dengan tujuan untuk mencegah perbaikan perlindungan. Dan yang kedua, yang sepenuhnya mewakili, yang diberikan pemerintah dengan tujuan untuk

${ }^{5} \mathrm{Https}$ //inet.detik.com/fotostop-news/d-2732821/7-kasus-pencurian-foto-yang-sampai-ke-meja-hijau (diakses pada 25 April 2020).

${ }^{6}$ http://tesishukum.com/pengertian-perlindungan-hukum-menurut-para-ahli/(diakses pada tanggal 24 April 2020). 
diselesaikan, disetujui yang diselesaikan dengan tujuan yang diselesaikan, diselesaikan dilakukan dengan meminta gugatan ke Pengadilan Niaga. ${ }^{7}$ Hal ini sesuai dengan Pasal 40 huruf K Undang-Undang No. 28 Tahun 2014 tentang Hak Cipta $^{8}$ yang menyatakan bahwa karya seni fotografi dilindungi hak ciptanya.

Berdasarkan uraian diatas, peneliti tertarik akan mengkaji dan menganalisis mengenai : Perlindungan Hukum Bagi Karya Fotografi Yang Diunggah Di Media Internet yang masih kerap kali dilakukan oleh oknum-oknum agar pencipta dan pemilik sebuah karya fotografi mendapat perlindungan hukum dan juga kepastian hukum.

\section{B. METODE PENELITIAN}

Metode penelitian yang digunakan dalam penelitian ini merupakan metode penelitian yuridis normatif. Metode yuridis normatif yakni penelitian yang erat hubungannya dengan perpustakaan karena akan membutuhkan bahan-bahan hukum sekunder pada perpustakaan yang memiliki arsip lengkap mengenai bahan hukum dan buku-buku. ${ }^{9}$ Soerjono Soekanto berpendapat bahwa penelitian hukum normatif meliputi penelitian terhadap asas-asas hukum, penelitian terhadap sistematika hukum, penelitian terhadap sinkronisasi hukum, penelitian sejarah hukum, dan penelitian perbandingan hukum. ${ }^{10}$ Metode yuridis normatif, difokuskan untuk mengkaji dan meneliti materi hukum dari Praturan Perundang-undangan UU No 28 Tahun 2014 tentang Hak Cipta.

Penelitian ini menggunakan 2 (dua) macam pendekatan, yakni pendekatan perundangundangan (Statute Approach) dan pendekatan kasus (Case Approach).

Penelitian ini bersifat deskriptif, yakni penelitian yang ditujukan untuk memdeskripsikan fenomena-fenomena yang ada, baik fenomena alamiah maupun fenomena buatan manusia. Fenomena tersebut bisa berupa bentuk, aktivitas, perubahan, karakteristik, hubungan, kesamaan, dan lain sebagainya. Dalam penelitian ini peneliti menggunakan beberapa teori hukum sebagai rujukan permasalahan yang sedang peneliti teliti. Beberapa teori tersebut yakni; Teori Perlindungan Hukum, Teori tentang Kepastian Hukum, dan Teori Hak Cipta.

\section{PEMBAHASAN}

Berdasarkan Pasal 1 angka 2 Undang-Undang No.28 Tahun 2014 tentang Hak Cipta ${ }^{11}$ menyatakan bahwa pencipta adalah seorang atau beberapa orang secara bersamasama atas inspirasinya melahirkan suatu ciptaan berdasarkan kemampuan pikiran, imajinasi, kecekatan, keterampilan atau keahlian yang dituangkan ke dalam bentuk yang khas dan bersifat pribadi. Artinya, bahwa seorang pencipta atau kreator merupakan seorang yang mampu membuat atau menghasilkan suatu imajinasi, keahlian maupun inovasi yang ada dalam dirinya yang kemudian diwujudkan dalam bentuk karya seni. Karya seni ini sebgaai hak pemilik atau pemegang kepunyaan si pencipta karya. Pemegang Hak Cipta berdasarkan Pasal 1 angka 4 Undang-Undang No.28 Tahun 2014 tentang Hak Cipta ${ }^{12}$ adalah Pencipta sebagai Pemilik Hak Cipta, atau pihak yang menerima hak tersebut dari Pencipta, atau pihak lain yang menerima lebih lanjut hak dari pihak yang menerima hak tersebut. Hak Cipa dapat dipindahtangankan kepada orang lain sesuai dengan kesepakatan masing-masing pihak yang bersangkutan.

\footnotetext{
${ }^{7}$ http://repository.unej.ac.id/handle/123456789/64963 diakses 21 April 2020

${ }^{8}$ Lihat Pasal 40 huruf K Undang-Undang No. 28 Tahun 2014 tentang Hak Cipta

${ }^{9}$ Koentjaraningrat.(1984). Metode-Metode Penelitian Masyarakat. Jakarta: Gramedia, hlm 13.

${ }^{10}$ Soerjono Soekanto.(2008). Pengantar Penelitian Hukum. Jakarta: UI Press, hlm. 52.

${ }^{11}$ Pasal 1 angka 2 Undang-Undang No.28 Tahun 2014 tentang Hak Cipta

${ }^{12}$ Https://dgip.go.id/images/ki-images/pdf-files/uu_pp1/uu_no_19_th_2002.pdf(diakses pada 28 April 2020).
} 
Menurut hemat peneliti, seorang fotografer dapat memindahtangankan kepemilikan atau hak cipta atas karyanya sesuai dengan persetujuan para pihak yang bersangkutan. ${ }^{13}$

Fotografer sebagai pemegang Hak Cipta karya seni fotografi memiliki Hak Eksklusif atas karya seni yang diciptakan, namun hak tersebut terbatas yang artinya bahwa seorang fotografer meskipun memilki Hak Eksklusif tetapi tidak berkuasa penuh atas karyanya tersebut. Hak Ekskulsif dalam hal ini dimaksudkan apabila seorang fotografer hendak mempublikasikan karyanya guna kepentingan komersial, maka harus meminta persetujuan kepada orang atau objek fotografinya terlebih dahulu. Misalkan, fotografer A memngerjakan pekerjaannya tersebut dimna ojkek fotonya adah seorang model B. Maka jika Fotografer A Ingin memposting karyanya yang terdapatt model B didalamnya, ia harus izin terlebih dahulu terhadap si model B. Persetujuan tersebut dimaksudkan agar dikemudian hari orang atau objek pemotretan tersebut tidak merasa keberatan atas hasil potretnya yang hendak dipublikasikan. ${ }^{14}$ Jika objek pemotretan atau orang yang bersangkutan tidak menyetujui potretnya untuk dipublikasikan ke khalayak umum maka sang fotografer juga tidak boleh mempublikasikannya.

Seorang fotografer dapat juga menggunakan hasil pemotretannya tanpa meminta izin dari objek foto yang bersangkutan jika dengan tujuan untuk pertunjukan umum atau untuk diumumkan ke khalayak luas walaupun untuk kepentingan komersial tetapi yang bersangkutan menyetujuinya, maka hukumnya diperbolehkan. Namun jika seorang fotografer memotret suatu pertunjukan umum untuk kepentingan dirinya ataupun untuk kepentingan komersial jika yang bersangkutan melarangnya atau merasa keberatan maka sang fotografer harus merelakan hasil jepretannya untuk dihapus. ${ }^{15}$

Adanya kasus-kasus seperti yang telah peneliti jelaskan di atas, jika seorang mempublikasikan hasil fotografinya tanpa meminta izin dari objek atau pihak yang bersangkutan dan mengambil foto hasil karya orang lain tanpa seizinnya, maka dapat dikenai Pasal 12 ayat 1 UndangUndang No. 28 Tahun 2014 tentang Hak Cipta yang berbunyi "setiap orang dilarang melakukan penggunaan secara komersial, penggandaan, pengumuman, pendistribusian, dan atau komunikasi atas potret yang dibuatnya guna kepentingan reklame atau periklanan secara komersial tanpa persetujuan tertulis dari orang yang dipotret atau ahli warisnya.", Pasal 40 huruf k Undang-Undang No. 28 Tahun 2014 tentang Hak yang berbunyi " ciptaan yang dilindungi meliputi meliputi ciptaan dalam bidang ilmu pengetahuan, seni, dan sastra, terdiri atas...(k). Karya fotografi." Dan Pasal 44 ayat 1 Undang-Undang No. 28 Tahun 2014 tentang Hak cipta. Jika melanggar pasal tersebut maka seseorang itu termasuk melanggar hak si pencipta karya.

Pelanggaran hak cipta dapat diartikan sebagai perbuatan mengambil, mengutip, merekam, memperbanyak, dan mengumumkan sebagian atau seluruh karya cipt amilik orang lain, tanpa sepengetahuan dan seizin pencipta atau pemegang hak cipta. Pada kenyataannya, tindakan tersebut sering dilakukan untuk memenuhi kepentingan komersial atau demi memperoleh keuntungan pribadi ataupun untuk kepentinggan lainnya. Yang dapat digolongkan sebagai pelanggaran hak cipta yaitu apabila perbuatan tersebut mengarah pada pelanggaran hak eksklusif yang melekat pada diri pencipta atau pemegang hak cipta.

Hal-hal yang demikian perlu adanya dasar pengaturan yang kuat agar tidak timbul problematika terkait munculnya tuntutan akan perlindungan hak cipta. Disamping itu juga untuk menghindari tumpang tindih pengakuan atau klaim sana sini diantara pihak-pihak yang merasa dirinya berhak atas hak cipta suatu karya cipta atau produk.

\footnotetext{
${ }^{13}$ Usman, Rachmadi.(2002). Hukum Hak Atas Kekayaan Intelektual: Perlindungan dan Dimensi Hukumnya di Indonesia. Bandung: PT. Alumni, hlm. 62.

${ }^{14}$ Sembiring, Sentosa.(2006). Hak Kekayaan Intelektual Dalam Berbagai Peraturan Perundang-undangan. Bandung: Yrama Widya, hlm. 75.

${ }^{15}$ Ibid.
} 
Berdasrkan kasus yang sudah dijabarkan diatas, Dengan adanya pengaturan terkait hak cipta potret (mengambil atau memfoto dengan objek orang ) sebagaimana dalam Pasal 1 angka 10 Undang-Undang Nomor 28 Tahun 2014 yang mengatur bahwa Potret adalah karya fotografi dengan objek manusia, seharusnya sudah memberikan kepastian kepada para pencipta mengenai pelanggaran hak cipta sudah dapat dibatasi. Dikarenakan apabila pelanggaran itu tetap dibiarkan untuk terjadi atau bahkan justru semakin meningkat akan menimbulkan banyak kerugian disalah satu pihak, baik itu kerugian secara ekonomis ataupun moral sekalipun. Adanya pelanggaran hak cipta tersebut pasti dipengaruhi oleh beberapa faktor, diantaranya karena rendahnya pemahaman akan arti dan fungsi hak cipta dan keinginan untuk memperoleh keuntungan ekonomis dari kemampuan daya jual dari sebuah karya cipta. Disamping itu juga masih kurangnya masyarakat untuk mendaftarkan hak cipta atas suatu hasil ciptaan. Terlepas daripada itu, bahwa suatu ciptaan ketika dilahirkan sudah melekat asas deklaratif sebagaimana yang sudah dijelaskan sebelumnya, namun dengan mendaftarkan sebuah karya cipta akan membuktikan bahwa ciptaan itu benar merupakan ciptaannya dan agar orang lain tidak dapat mengakui dan menggunakan ciptaan itu tanpa seijin dan sepengetahuan si pencipta. Dengan memperhatikan pentingnya permasalahan potret yang digunakan tanpa ijin pencipta atau orang yang dipotret akan meningkatkan persaingan yang sehat di dunia seni dan meningkatkan kreatifitas dan inovasi untuk terus menciptakan karya-karya yang baru, maka sudah waktunya untuk memberikan perhatian akan perlindungan hukum terhadap karya cipta potret ini. ${ }^{16}$ dengan perlindungan hukum maka akan terjamian keamaan sang fotografer yang karyanya dipakai orang lain tanpa seizinnya maupun bagi si objek foto (manusia) yang dijadikan objek dalam karya fotografi seorang fotogafer.

Di Indonesia aturanyang mengatur menegnai perlindungan hak cipta adalah UU No.28 Tahun 2014 tentang Hak Cipta. Di dalam UU ini, karya fotografi masuk dalam jenis hak kekayaan intelektual khususnya hak cipta dalam pasal 40 ayat 1 huruf $\mathrm{k}$ tersebut mencakup semua foto yang didapatkan atau diciptakan melalui kamera. Dalam pasal 40, menyebutkan bahwa "ciptaan yang dilindungi meliputi ciptaan dalam bidang ilmu pengetahuan, seni, dan sastra, yang terdiri atas....". karena fotografi termasuk dalam ranah seni, maka bukan hal yang baru bahwa karya fotografi merupakan salah satu karya seni yang dilindungi dalan UU Hak cipta. Karya fotografi merupakan karya yang dilindungi secara eksklusif dalam UU Hak Cipta, sebagaimana diatur dalam pasal 4 UUHC bahwa "hak cipta adalah hak eksklusif yang mengandung dua esensi hak yakni moral dan juga ekonomi.".

Hak Moral lebih kepada pengakuan masyarakat atas eksistensi diri pencipta sebagai pemilik atas suatu karya. Hak Cipta memberi sanksi immateriil yakni beban moral yang harus ditanggung oleh pelanggar Hak Cipta. Pada kasus pelanggaran Hak Cipta atas karya fotografi, maka saknsi moral yang akan melekat pada dirinya. Hal ini bisa berpotensi menghambat kemajuan karirnya sebagai fotografer.

Hak moral tidak boleh dihilangkan maupun dipisahkan dan hanya dapat dijalankan oleh pemegang Hak Cipta atau jika pemegang Hak Cipta meminta pihak lain untuk menjalankannya. Hak moral adalah suatu refleksi kepribadian dari pencipta atau pemegang hak cipta sedangkan hak ekonomi adalah suatu refleksi dari kebutuhan pencipta atau pemegang hak cipta. Hak moral tetap harus diakui serta dihormati oleh semua pihak meski pencipta atau pemegang hak cipta sudah meninggal dunia. ${ }^{17}$ Untuk melindungi hak moral pencipta dapat memiliki informasi manajemen hak cipta yang meliputi tentang metode atau sistem yang mengindentifikasi

\footnotetext{
${ }^{16}$ Ganis Dhenandapinasthi Permana.(2018). Pelindungan Hak Cipta Potret di Indonesia (Studi Kasus Penggunaan Potrer untuk Vidio Klip Akad Nikah Payung Teduh), Progam Studi Ilmu Hukum, Yogyakarya: Fakultas Hukum Universitas Islam Indonesia.

${ }^{17}$ Swari\& Subawa.(2018). Perlindungan Hukum Lagu Yang Diunggah Tanpa Izin Pencipta atau pemegang hak cipta Di Situs Youtube. Kertha Semaya: Journal Ilmu Hukum, 6(10), 7-8
} 
originalitas substansi ciptaan dan penciptanya, serta kode informasi dan kode akses. Sedangkan informasi elektronik hak cipta meliputi informasi tentang suatu ciptaan, yang muncul dna melekat secara elektronik dalam hubungan dengan kegiatan pengumuman ciptaan yang berupa nama pencipta, aliasnya atau nama samarannya, pencipta sebagai pemegang hak cipta, masa dan kondisi penggunaan ciptaan, nomor, dan kode informasi. ${ }^{18}$ Penggunaan nama pencipta, aliasnya atau nama samarannya, pencipta sebagai pemegang hak cipta, masa dan kondisi penggunaan ciptaan, nomor, dan kode informasi tersebutdimaksudkan agar menjamin perlindungan hukum pencipta karya atau si fotografer. Hak moral tersebut sudah dianggap sebagai hak pribadi yang dimiliki oleh seorang pencipta untuk mencegah terjadinya penyimpangan atas karya ciptanya dan untuk mendapatkan penghormatan atau penghargaan atas karyanya tersebut. Dengan adanya Hak moral tersebut dapat mewujudkanan hubungan antara si pencipta dengan hasil karya ciptaannya agar terus berlangsung.

Jadi, dengan hak moral, pencipta dari suatu karya cipta memiliki hak untuk:

a. Namanya dicantumkan sebagai pelaku pertunjukan, kecuali disetujui sebaliknya,

b. Tidak dilakukannya distorsi ciptaan, mutilasi ciptaan, modifikasi ciptaan, atau hal-hal yang bersifat merugikan kehormatan diri atau reputasinya kkecuali disetujui sebaliknya. ${ }^{19}$

Sedangkan hak ekonomi pencipta atau pemegang hak cipta dalam UUHC yang baru mengatur secara khusus Hak Ekonomi di dalam Pasal 8-17 UUHC 2014. Sebelumnya hak ekonomi tidak diatur dalam UUHC 2012, pengertian hak ekonomi hanya di atur dalam penjelasan UUHC 2012.10 Adapun hak ekonomi dalam UUHC 2014 yakni disebutkan dalam Pasal 8 dan 9 ayat (1) UUHC 2014 yang menyatakan bahwa "hak ekonomi adalah hak eksklusif pencipta atau pemegang hak cipta demi memperoleh manfaat ekonomi dari suatu karya cipta". Hak ekonomi yang dilakukan oleh pencipta atau pemegang hak cipta yakni seperti :

a. Menerbitkan ciptaan;

b. Menggandakan ciptaan dalam berbagai bentuknya;

c. Menerjemahkan ciptaan;

d. Mengadaptasi, mengaransemen/mentransformasi ciptaan;

e. Mendistribusikan ciptaan/salinannya;

f. Menunjukkan ciptaan;

g. Mengumumkan ciptaan;

h. Mengkomunikasikan ciptaan; dan

i. Menyewakan ciptaan;

Bagi setiap orang yang melaksanakan hak ekonomi tersebut wajib mendapatkan izin pencipta atau pemegnag hak cipta dan dalam Undang-undang Hak Cipta juga disebutkan larangan bagi siapapun untuk melakukan penggadaan dan atau penggunaan secara komersial suatu ciptaan. ${ }^{20}$ Larangan menggunakan suatau kary afotografi yang bukan miliknya ini masih kerap terjadi dan dengan mudah seseorang hanya tinggal mengambil data karya tersebut diinternet.

Larangan dalam memperbanyak atau menggunakan suatu karya cipta termasuk karya fotografi demi kepentingan komersial tanpa izin pencipta atau pemegang hak cipta juga sudah diatur dalam Pasal 9 ayat (3) UUHC 2014. Jika suatu karya cipta digunakan untuk kepentingan komersial tidak bisa seenaknya dipakai, namun harus mendapatkan izin terlebih dahuu.. Meski peraturan perunsnag-undangan telah jelas mengatur bahwa hak ekonomi yaitu suatu hak eksklusif pencipta atau pemegang Hak Cipta, masih saja terdapat oknum-oknum yang menggunakannya tanpa izin. Dari sekian hak ekonomi pencipta atau pemegang Hak Cipta yang sering dilakukan oleh pelanggar Hak Cipta dari karya fotografi seperti menerbitkan tanpa

\footnotetext{
${ }^{18}$ Bambang sunggono.(2011). Metode Penelitian Hukum, Jakarta: Raja Grafindo Persada, hlm. 45.

${ }^{19}$ Pasal 22 UU No.28 Tahun 2014 tentang Hak Cipta

${ }^{20}$ Pasal 9 ayat (3) UUHC 2014
} 
diberi nama pencipta asli, tidak memiliki izin untuk mempostingkarya orang, menggandakan maupun mendistribusikan ciptaan ataupun salinannya.

Seharusnya jika ingin menggunakan atau menggandakan suatu potere seseorang harus mendapat izin tertulis atau lisensi dari pemegang hak cipta. Pada Pasal 80 ayat 1 UU No.28 tahun2014 Tentang Hak Cipta, Hak Cipta menyatakan "Kecuali diperjanjikan lain, pemegnag Hak Cipta atau pemilik Hak Terkait berhak meberikan Lisensi kepada pihak lain berdasarkan perjanjian tertulis untuk melkasanakan perbuatan sebagaimana yang dmaksud dalam pasal 9 ayat 1, Pasal 23 ayat 2, Pasal 24 ayat 2, dan Pasal 25 ayat 2 UU No.28 tahun2014 Tentang Hak Cipta. ${ }^{21}$

Agar terhindar dari pelanggaran Hak Cipta sangat penting kita perlu membekali diri dengan pengetahuan mengenai penggunaan Hak Cipta di ranah digital. Bahkan, foto dengan lisensi Creative Commons yang dianggap "aman" untuk digunakan secara bebas namun ada beberapa jenis yang tidak dapat digunakan maupun dipublikasikan secara sembarangan. Maka, perlu mengetahui mengenai jenis-jenis hak cipta sebagai berikut :

a. Hak cipta tradisional

Pemilikfotoataugambardengan hakcipta memeganghakciptapenuhterhadapkaryanya. Artinya, foto tersebut tidak dapat digunakan, diperbanyak, atau disetujui tanpa izin dari pemiliknya. Seluruh foto atau gambar orisinil dilindungi oleh hak cipta ini.

b. Area publik

Jika menemukan foto atau gambar dengan Lisensi Domain Publik, pemilik sang pemilik harus mengirimkankaryanyakepada domain publik. Dengankatalainbisamenggunakan,mengatur, membandingkan, dan mengubah foto bebas, untuk kepentingan komersial sekali pun.

c. Creative commons

Foto atau gambar di internet yang ditandai dengan ikon CC, seharusnya, foto tersebut memiliki lisensi creative commons . Foto dengan Lisensi CC dapat digunakan tanpa izin pemilik, tetapi ada beberapa ketentuan yang berlaku, yakni :

1) Atribusi : harus mengutip sumber foto atau gambar sesuai dengan cara yang ditentukan oleh pencipta atau izin lisensi kamu menggunakan, lisensi, atau membagikan karya mereka.

2) Non-komersial : bolehmenggunakan,mendistribusikan, danmembagikanfotoatau gambar hanya untuk tujuan nonkomersial.

3) Tidak ada karya turunan : boleh menggunakan, mentransfer, dan mengumpulkan foto atau gambar, tetapi tidak boleh disetujui sama sekali. ${ }^{22}$

Berdasarkan paparan diatas, Pelanggaran hak cipta pada dasarnya ada 2 yaitu pelanggaran terhadap hak moral dan pelanggaran terhadap hak ekonomi pencipta. ${ }^{23}$ Pelanggaran terhadap hak moral dapat dilakukan dengan gugatan perdata atau ganti rugi, sedangkan pelanggaran terhadap hak ekonomi merupakan pelanggaran yang dikategorikan sebagai tindak pidana, dan untuk menyelesaikan perkara pelanggaran hak ekonomi adalah melalui pengadilan niaga. ${ }^{24}$ Pelanggaran hak ekonomi ini dikualifikasikan sebagai pelanggaran pidana untuk memperlihatkan, mendistribusikan atau menjual materi hasil pelanggaran hak cipta. ${ }^{25}$

\section{Upaya Perlindungan Hukum Penyelesaian sengketa Hak Cipta Fotografi:}

Perlindungan Hukum memberikan pengayoman kepada hak asasi manusia yang dirugikan dengan orang lain dan perlindungan tersebut diberikan kepada masyarakat agar mereka dapat

\footnotetext{
${ }^{21}$ Pasal 80 ayat 1 UU No.28 Tahun2014 Tentang Hak Cipta

${ }^{22} \mathrm{https}$ ://id.techinasia.com/talk/hak-cipta-foto-bagi-pemasar-digital diterbitkan pada 14 juli 2020

${ }^{23}$ Khoirul Hidayah.(2012). Hukum HKI Hak Kekayaan Intelektual Di Indonesia. Malang: UIN-Maliki Press. Hlm. 51

${ }^{24}$ Ibid.

${ }^{25}$ Endang Purwaningsih.(2005). Perkembangan Hukum Intellectual Property Rights Kajian Hukum terhadap Hak atas Kekayaan Intelektual dan Kajian Komparatif Hukum Paten, Bogor: Ghalia Indonesia, hlm. 6.
} 
menikmati semua hak-hak yang diberikan oleh hukum atau dengan kata lain perlindungan hukum adalah berbagai upaya hukum yang harus diberikan oleh aparat penegak hukum untuk memberikan rasa aman, baik secara pikiran maupun fisik dari gangguan dan berbagai ancaman dari pihak manapun. ${ }^{26}$ Menurut pendapat Philipus M. Hadjon, perlindungan hukum bagi rakyat sebagi tindakan pemerintah yang bersifat preventif dan represif. ${ }^{27}$ Dengan kata lain Perlindungan Hukum memiliki suatu konsep dimana hukum dapat memberikan suatu keadilan, ketertiban, kepastian, kemanfaatan dan kedamaian.

Perlindungan pada Hak Cipta memiliki arti yang sangat penting bagi para pencipta suatu karya seni. Perlindungan pada Hak Cipta selain melindungi sebuah karya seni juga berfungsi untuk menghindarkan dari segala bentuk plagiarisme, pencurian hak milik dan lain sebagainya, namun yang terpenting yakni melindungi segala hak-hak yang dimilki oleh seorang fotografer yang ketentuannya telah diatur dalam Undang-Undang Hak Cipta.Hak-hak tersebut juga berguna untuk menjaga reputasi fotografer selaku pencipta karya seni. Hak-hak yang dimaksudkan juga termasuk di dalamnya yakni Hak Ekonomi (hak untuk memperoleh keuntungan materiil dari sebuah karya seni ciptaanya) dan juga Hak Moral (pengakuan masyarakat akan eksistensi sang fotografer selaku pemilikkarya seni hasil ciptaanya). Namun hal ini justru berbanding terbalik bahwa dengan adanya Perlindungan Hak Cipta memberikan banyak kerugian bagi pihak yang telah melanggar ketentuan Hak Cipta ini. Tidak saja kerugian materiil yang dialami oleh pelaku pelanggaran Hak Cipta ini, akan tetapi yang lebih buruk lagi menimbulkan kerugian immateriil baginya. Kerugian materiil bagi pihak-pihak yang melanggar ketentuan Hak Cipta dapat berupa dijatuhinya sanksi pidana, perdata, maupun administratif. Selain sanksi materiil yang dapat dijatuhkan pada para pihak yang melanggar ketentuan Hak Cipta, sanksi yang tidak dapat terlepas dari pihak-pihak yang melanggar Hak Cipta adalah sanksi immateriil yaitu beban moral yang harus ditanggung oleh pelanggar Hak Cipta. Pada kasus pelanggaran Hak Cipta atas suatu karya seni fotografi, apabila pihak yang melanggar tersebut adalah sama-sama sebagai fotografer, maka sanksi moral yang akan terus melekat pada dirinya adalah tidak lagi dianggap sebagai fotografer yang memilki ide-ide, kreatifitas, serta keorisinalitasan sendiri. Tindakan ini jelas akan menghambat kemajuan kariernya sebagai seorang fotografer di masa sekarang dan kariernya sebagai fotografer di masa yang akan datang. ${ }^{28}$ Perlindungan hukum terhadap karya fotografi tidak perlu mendaftar terlebih dahulu karena secara otomatis setelah karya fotografi tersebut sudah berupa bentuk nyata dan nyata sudah dipamerkan ke khalayak umum maka karya tersebut telah memperoleh pengakuan Hak Cipta dan mendapatkan perlindungan hukum. Akan tetapi kepentingan pendaftaran terhadap karya fotografi adalah untuk kepentingan pemuktian apabila di kemudian hari timbul sengketa yang berkaitan dengan karyanya.

Perlindungan hukum terhadap pelanggaran Hak Cipta telah dilakukan melalui upayaupaya hukum oleh para pihak yang telah diterapkan sanksi-sanksi terhadap pelanggar hak cipta berdasarkan Undang-Undang No.28 Tahun 2014 tentang Hak Cipta. Sanksi diberikan kepada para oknum-oknum yang telah mengumumkan sebuah karya fotografi yang bersifat komersial tanpa meminta izin atau persetujuan dari seseorang yang menjadi objek pemotretan. Sanksi juga diberikan kepada seseorang yang menggunakan hasil karya cipta potret yang dimiliki fotografer tanpa meminta izin terlebih dahulu kepada fotografer. Orang tersebut menggunakan hasil karya cipta potret yang dimiliki oleh fotografer tanpa meminta izin untuk mempublikasikannya. Sehingga fotografer yang menggunakan foto atau potret seseorang untuk komersial tanpa meminta izin atau orang lain yang menggunakan hasil karya cipta potret

\footnotetext{
${ }^{26}$ Satjipto Raharjo.(2000).Ilmu Hukum. Bandung: Pt Citra Aditya Bakti, hlm. 74.

${ }^{27}$ Philipus M. Hadjon.(1987). Perlindungan Hukum bagi Rakyat Indonesia. Surabaya: PT. Bima Ilmu, hlm. 85.

${ }^{28}$ Nurul Liza Anjani,dkk "Perlindungan Karya Seni Fotografi Berdasarkan Undang-Undang No.19 Tahun 2002 Tentang Hak Cipta” Jurnal Hukum, 2012.
} 
yang dimilki oleh fotogarfer tanpa meminta izin dapat dikenakan sanksi berdasarkan UndangUndang No.28 Tahun 2014 tentang Hak Cipta. ${ }^{29}$ Dalam hal ini seseorang yang beranii berbuat maka ia juga harus berani bertanggung jawab, untuk membuktikan apakah benar bahwa karya tersebut memang asli hasil karnyany aatau karangan orang lain.

Pengaturan Perlindungan Hukum Karya Cipta Fotografi dapat ditempuh dengan dua jalur yaitu :

1. Jalur litigasi/ pengadilan

2. Jalur alternatif penyelesaian di luar pengadilan

Jalur litigasi dimana dalam jalur litigasi ini dibagi menjadi dua macam yakni jalur Perdata dan jalur pidana. Untuk jalur perdata ditempuh melalui suatu proses gugatan ganti kerugian di Pengadilan Niaga. Sedangkan untuk jalur pidana prosedurnya adalah dari pelaporan pihak yang dirugikan kepada instansi yang berwenang.

Sedangkan untuk upaya hukum lain ditempuh melalui jalur non-litigasi dikenal sebagai alternatif penyelesaian sengketa. Alternatif penyelesaian sengketa sering diartikan sebagai alternative to litigation, namun seringkali juga diartikan sebagai alternative to adjudication. Pemilihan terhadap salah satu dari dua pengertian tersebut menimbulkan implikasi yang berbeda. Apabila pengertian yang pertama menjadi acuan alternative to litigation, maka mencakup seluruh mekanisme alternatif penyelesaian sengketa di luar pengadilan

Secara umum, perlindungan karya cipta fotografi diatur dalam pasal 40 ayat (1) UndangUndang No. 28 Tahun 2014 tentang Hak Cipta. Perlindungan Hak Cipta atas karya fotografi dapat dilakukan dengan 2 (dua) cara, yaitu dengan cara preventif yaitu perlindungan yang diberikan pemerintah dengan tujuan untuk mencegah terjadinya pelanggaran dengan melakukan pendaftaran Hak Cipta. Dan perlindungan dengan cara represif yaitu perlindungan yang diberikan pemerintah dengan tujuan untuk menyelesaikan sengketa apabila terjadi pelanggaran terhadap Hak Cipta atas Karya Fotografi dengan cara melakukan gugatan ke Pengadilan Niaga.

Hak-hak yang dimiliki oleh seorang Pencipta yakni Hak Ekonomi dan Hak Moral, dimana Hak Ekonomi diatur pada pasal 8 sampai dengan pasal 11 UUHC, sedangkan hak moral diatur pada pasal 5 ayat (1) UUHC. Setiap orang yang melaksanakan hak ekonomi atas suatu ciptaan milik orang lain wajib mendapatkan izin Pencipta atau Pemegang Hak Cipta setiap orang yang tanpa izin Pencipta atau Pemegang Hak Cipta dilarang melakukan Penggadaan dan/atau Penggunaan Secara Komersial ciptaan. ${ }^{30}$

a. Tanggung gugat atas Pelanggaran Hak Cipta

Menurut ahli hukum perdata J.H. Niewenhuis merupakan kewajiban untuk menanggung kerugian sebagai akibat pelanggaran norma. Niewen Huis juga menguraikan bahwa tanggung gugat itu bertumpu pada dua tiang yaitu pelanggaran hukum dan kesalahan. ${ }^{31}$ Tanggung gugat pada pelanggaran hak cipta terjadi ketika suatu perbuatan yang dilakukan mengarah pada pelanggaran hak eksklusif pencipta atau pemegang hak cipta. Jika ditemukan pelanggaran hak cipta, pencipta dan pemegang hak cipta tersebut dapat mengajukan permohonan penetapan sementara ke pengadilan niaga, mengajukan gugatan ganti rugi ke pengadilan niaga, serta melaporkan pelanggaran tersebut kepadapenyidik dari POLRI dan/atau PPNS Dirjen HKI. Permohonan penetapan sementara diajukan untuk mencegah berlanjutnya pelanggaran hak

${ }^{29}$ Eva Puspitarani, "Perlindungan Hukum Terhadap Potret Orang Lain Yang Digunakan Promosi Oleh Fotografer Berdasarkan Undang-Undang No.19 Tahun 2002 tentang Hak Cipta” Jurnal Hukum, 2013.

${ }^{30}$ Jurnal Dewa Ayu Pringga Aristya Dewi, A.A Sagung Wiratni Darmadi, Pengaturan Perlindungan Karya Cipta Fotografi Yang di Ambil Tanpa Izin Melalui Media Sosial Berdasarkan Undang-Undang No.28 Tahun 2014 Tentang Hak Cipta, Program Kekhususan Hukum Bisnis Fakultas Hukum, Universitas Udayana, diterbitkan di ojs.unud.ac.id

${ }^{31}$ Paulus Aluk Fajar Dwi Santo, Mempertanyakan Konsepsi Tanggung Gugat, terdapat dalam http://business-law.binus. ac.id/2020/07/10/ mempertanyakan-konsepsi-tanggung-gugat. Mei, 2016, diakses tanggal 10 Juli 2020. 
cipta. ${ }^{32}$ Pihak yang melakukan pelanggaran hak cipta dapat bertanggung gugat atas kerugian yang dialami oleh pencipta atau pemegang hak cipta, serta wajib mengganti kerugian. Bentuk ganti rugi bisa berupa biaya yang dibebankan kepada pelanggar hak cipta. Sebagai bentuk ganti rugi atas penggunaan karyanya oleh pihak lain. ${ }^{33}$

b. Penjatuhan sanksi atas pelanggaran hak cipta

Seorang dapat dikenakan pasal tersebut jika mempublikasikan hasil pemotretannya tanpa meminta izin terlebih dahulu sehingga telah melanggar ketentuan pada pada Pasal 19 dan Pasal 20 Undang-Undang No.28 Tahun 2014 tentang Hak Cipta dengan ancaman pidana penjara paling lama 2 tahun dan/atau denda paling banyak Rp. 150.000.000,00 (seratus lima puluh juta rupiah). Jika seorang fotografer yang dengan sengaja dan dengan menyadari bahwa jika mengumumkan atau mempublikasikan potret orang lain tanpa meminta izin terlebih dahulu dapat melanggar ketentuan Undang-Undang No.28 Tahun 2014 tentang Hak Cipta, namun tetap saja mempublikasikannya ke khalayak umum untuk berbagai kepentingan misalnya untuk kepentingan iklan ataupun untuk kepentingan promosi yang bersifat komersial, maka dapat dikenai Pasal 72 ayat (5) Undang-Undang RI No.28 Tahun 2014 tentang Hak Cipta. Ketentuan pada pasal tersebut bahwa apabila pemegang hak cipta tetap mempublikasikan hasil karya fotografinya dengan sengaja tanpa meminta izin terlebih dahulu pada yang bersangkutan. Apabila sebelum mempublikasikan telah mendapat persetujuan dari seseorang yang menjadi objek dan menyatakan tidak keberatan jika hasil potret dirinya dipublikasikan maka pasal tersebut tidak berlaku.

Dapat dilihat pada Pasal 112 Undang-Undang No. 28 tahun 2014 mengenai ketentuan pidananya yang berbunyi: Setiap orang yang dengan tanpa hak melakukan perbuatan sebagaimana dimaksud dalam Pasal 7 ayat (3) dan/atau Pasal 52 untuk Penggunaan Secara Komersial, dipidana dengan pidana penjara paling lama 2 (dua tahun dan/atau pidana denda paling banyak Rp 300.000.000,00 (tiga ratus juta rupiah) Tetapi kembali keputusan mengenai besaran sanksi yang dijatuhkan tergantung dari keyakinan yang dimiliki oleh hakim itu sendiri.

Dari bebrapa pasal yang mengatur mengenai ketentuan pidana pelanggaran hak cipta, maka dapat ditarik garis besar bahwa tindak pidana bidang hak cipta dikategorikan sebagai tindkakejahatan dengan ancaman hukuman yang bervariasi. Hal yan gmenggembirakan adalah dalam tindak pidana tertentu, sanksi pidananya ditentukan, baik miminum maupun maksimum, dengan ancaman yang bersifat kumulatif alternative sehingga terhindar dari penjatuhan vonis yang terlalu rendah. ${ }^{34}$

\section{KESIMPULAN}

Sebuah karya seni fotografi yang diciptakan oleh seorang fotografer membuat khayayakmasyarakat umum melirik, bisa merasakan ungkapan-unkapa perasaan yang terkandung didalam karya seni fotografi. Perlindungan hukum ini diberian untuk menjamin hakhak pencipta karya dalam bentuk pencegahan. Perlindungan hukum terhadap karya fotografi, ketentuannya telah diatur dalam UU No.28 Tahun 2014 tentang Hak Cipta namun masih saja banyak yang menentang Hak Cipta yang dilakukan oleh beberapa oknum dengan berbagai alasan seperti alasan komersial atau alasan non komersial. Karena itu, agar terhindar dari

${ }^{32}$ Sudaryat-Sudjana-Ratna Permata.(2010). Hak Kekayaan Intelektua., Bandung: Oase Media hlm. 53-54.

${ }^{33}$ Nidya Silvia Irfana.(2015). "Tanggung Gugat X Terhadap Y Terkait Kasus Pelanggaran Hak Cipta Berupa Artikel Ditinjau dari UU No 19 Tahun 2002 tentang Hak Cipta”, Jurnal Hukum, Edisi No. 4 Vol. 2, Fakultas Hukum Universitas Surabaya, hlm. 13.

${ }^{34}$ Ganis Dhenandapinasthi Permana,Pelindungan Hak Cipta Potret di Indonesia (Studi Kasus Penggunaan Potrer untuk Vidio Klip Akad Nikah Payung Teduh), Progam Studi Ilmu Hukum, Fakultas Hukum Universitas Islam Indonesia, Yogyakarya, diterbitkan tahun 2018. 
melanggar Hak Cipta perlu dilengkapi dengan pengetahuan tentang penggunaan Hak Cipta di ranah digital. Pemilik foto atau gambar dengan hak cipta memegang hak penuh terhadap karyanya. Artinya, foto tersebut tidak dapat digunakan, diperbanyak, atau diubah tanpa izin dari pemiliknya. Pada kasus pelanggaran Hak Cipta atas suatu karya seni fotografi, apabila pihak yang melanggar tersebut adalah sama-sama berprofesi sebagai fotografer, maka sanksi moral yang akan terus melekat pada dirinya adalah fotografer tidak lagi dianggap sebagai fotografer yang memilki ide-ide, kreatifitas, serta keorisinalitasan sendiri. Tindakan ini jelas akan menghambat kemajuan kariernya sebagai seorang fotografer di masa sekarang dan kariernya sebagai fotografer di masa yang akan datang. Untuk yang berkaitan dnegan hak ekonomi Penjatuhan sanksi atas pelanggaran hak cipta Seorang dapat dikenakan pasal tersebut jika mempublikasikan hasil pemotretannya tanpa meminta izin terlebih dahulu sehingga telah melanggar ketentuan pada pada Pasal 19 dan Pasal 20 Undang-Undang No.28 Tahun 2014 tentang Hak Cipta dengan ancaman pidana penjara paling lama 2 tahun dan/atau denda paling banyak Rp. 150.000.000,00 (seratus lima puluh juta rupiah). mempublikasikannya ke khalayak umum untuk berbagai kepentingan misalnya untuk kepentingan iklan ataupun untuk kepentingan promosi yang bersifat komersial, maka dapat dikenai Pasal 72 ayat (5) UndangUndang RI No.28 Tahun 2014 tentang Hak CiptaPasal 112 Undang-Undang No. 28 tahun 2014 yang ketentuan pidananya yang berbunyi: Setiap orang yang dengan tanpa hak melakukan perbuatan sebagaimana dimaksud dalam Pasal 7 ayat (3) dan/atau Pasal 52 untuk Penggunaan Secara Komersial, dipidana dengan pidana penjara paling lama 2 (dua tahun dan/atau pidana denda paling banyak Rp 300.000.000,00 (tiga ratus juta rupiah) Tetapi kembali keputusan mengenai besaran sanksi yang dijatuhkan tergantung dari keyakinan yang dimiliki oleh hakim itu sendiri. Jadi, seorang pencipta sebuah karya seni fotogafi dalam hal menghadapi sengketa karyanya, pencipa dan pemilik dari karya seni ini dilindungi oleh hukum yang tertuang dalam UU No.28 Tahun 2014 Tentang Hak Cipta. Dengan adanya peraturan tersebut, memberikan perlindungan hukum dan kepastianhukum terhadap pencipta karya atau fotografer untuk menlindungi dan menjaga keaslian karyanya.

\section{DAFTAR PUSTAKA}

\section{Buku}

Andy Noorman Sommeng.(2007). Penegakan Hukum Di Bidang Hak Kekayaan Intelektual, Direktorat. Tanggerang: Jenderal Hak Kekayaan Intelektual.

Iswi Hariyani.(2010). Prosedur Mengurus HAKI yang benar, Yogyakarta: Pustaka Yustisia.

Koentjaraningrat.(1984). Metode-Metode Penelitian Masyarakat. Jakarta: Gramedia.

Soerjono Soekanto.(2008). Pengantar Penelitian Hukum. Jakarta: UI Press.

Usman, Rachmadi.(2002). Hukum Hak Atas Kekayaan Intelektual: Perlindungan dan Dimensi Hukumnya di Indonesia. Bandung: PT. Alumni.

Sembiring, Sentosa.(2006). Hak Kekayaan Intelektual Dalam Berbagai Peraturan Perundangundangan. Bandung: Yrama Widya.

Ganis Dhenandapinasthi Permana.(2018). Pelindungan Hak Cipta Potret di Indonesia (Studi Kasus Penggunaan Potrer untuk Vidio Klip Akad Nikah Payung Teduh), Progam Studi Ilmu Hukum, Yogyakarya: Fakultas Hukum Universitas Islam Indonesia.

Swari\& Subawa.(2018). Perlindungan Hukum Lagu Yang Diunggah Tanpa Izin Pencipta atau pemegang hak cipta Di Situs Youtube. Kertha Semaya: Journal Ilmu Hukum, 6(10), 
Bambang sunggono.(2011). Metode Penelitian Hukum, Jakarta: Raja Grafindo Persada.

Khoirul Hidayah.(2012). Hukum HKI Hak Kekayaan Intelektual Di Indonesia. Malang: UINMaliki Press.

Endang Purwaningsih.(2005). Perkembangan Hukum Intellectual Property Rights Kajian Hukum terhadap Hak atas Kekayaan Intelektual dan Kajian Komparatif Hukum Paten, Bogor: Ghalia Indonesia.

Satjipto Raharjo.(2000).Ilmu Hukum. Bandung: Pt Citra Aditya Bakti.

Philipus M. Hadjon.(1987). Perlindungan Hukum bagi Rakyat Indonesia. Surabaya: PT. Bima Ilmu.

Nurul Liza Anjani,dkk "Perlindungan Karya Seni Fotografi Berdasarkan Undang-Undang No.19 Tahun 2002 Tentang Hak Cipta” Jurnal Hukum, 2012.

Eva Puspitarani, "Perlindungan Hukum Terhadap Potret Orang Lain Yang Digunakan Promosi Oleh Fotografer Berdasarkan Undang-Undang No.19 Tahun 2002 tentang Hak Cipta" Jurnal Hukum, 2013.

Jurnal Dewa Ayu Pringga Aristya Dewi, A.A Sagung Wiratni Darmadi, Pengaturan Perlindungan Karya Cipta Fotografi Yang di Ambil Tanpa Izin Melalui Media Sosial Berdasarkan Undang-Undang No.28 Tahun 2014 Tentang Hak Cipta, Program Kekhususan Hukum Bisnis Fakultas Hukum, Universitas Udayana, diterbitkan di ojs.unud.ac.id

Sudaryat-Sudjana-Ratna Permata.(2010). Hak Kekayaan Intelektual. Bandung: Oase Media.

Nidya Silvia Irfana.(2015). “Tanggung Gugat X Terhadap Y Terkait Kasus Pelanggaran Hak Cipta Berupa Artikel Ditinjau dari UU No 19 Tahun 2002 tentang Hak Cipta”, Jurnal Hukum, Edisi No. 4 Vol. 2, Fakultas Hukum Universitas Surabaya.

Paulus Aluk Fajar Dwi Santo, Mempertanyakan Konsepsi Tanggung Gugat, terdapat dalam http://business-law.binus.ac.id/2020/07/10/ mempertanyakan-konsepsi-tanggunggugat. Mei, 2016, diakses tanggal 10 Juli 2020.

Ganis Dhenandapinasthi Permana,Pelindungan Hak Cipta Potret di Indonesia (Studi Kasus Penggunaan Potrer untuk Vidio Klip Akad Nikah Payung Teduh), Progam Studi Ilmu Hukum, Fakultas Hukum Universitas Islam Indonesia, Yogyakarya, diterbitkan tahun 2018.

\section{Perundang-Undangan}

Pasal 1 ayat 1 UU No. 28 Tahun 2016 tentang Hak Cipta

Pasal 40 huruf K Undang-Undang No. 28 Tahun 2014 tentang Hak Cipta

Pasal 1 angka 2 Undang-Undang No.28 Tahun 2014 tentang Hak Cipta

Pasal 22 UU No.28 Tahun 2014 tentang Hak Cipta

Pasal 9 ayat (3) UUHC 2014

Pasal 80 ayat 1 UU No.28 Tahun2014 Tentang Hak Cipta

\section{Website}

Https://dgip.go.id/images/ki-images/pdf-files/uu_pp1/uu_no_19_th_2002.pdf (diakses pada 28 April 2020). 
Https://inet.detik.com/fotostop-news/d-2732821/7-kasus-pencurian-foto-yang-sampai-kemeja-hijau (diakses pada 25 April 2020).

http://tesishukum.com/pengertian-perlindungan-hukum-menurut-para-ahli/ (diakses pada tanggal 24 April 2020).

http://repository.unej.ac.id/handle/123456789/64963 diakses 21 April 2020

https://id.techinasia.com/talk/hak-cipta-foto-bagi-pemasar-digital diterbitkan pada 14 juli 2020 